$11-2000$

\title{
Another Look at the L'Ambiance Plaza Collapse
}

\author{
Rachel Martin \\ Washington University in St Louis
}

Norbert J. Delatte

Cleveland State University, n.delatte@csuohio.edu

Follow this and additional works at: https://engagedscholarship.csuohio.edu/encee_facpub

Part of the Civil Engineering Commons, and the Structural Engineering Commons

How does access to this work benefit you? Let us know!

Publisher's Statement

(c) ASCE

\section{Original Citation}

Martin, R., and Delatte, N. (2000). "Another Look at the L'Ambiance Plaza Collapse."

J.Perform.Constr.Facil., 14(4), 160-165.

This Article is brought to you for free and open access by the Civil and Environmental Engineering at EngagedScholarship@CSU. It has been accepted for inclusion in Civil and Environmental Engineering Faculty Publications by an authorized administrator of EngagedScholarship@CSU. For more information, please contact library.es@csuohio.edu. 


\title{
Another look at the L’Ambiance Plaza Collapse
}

\author{
By Rachel Martin ${ }^{1}$ and Norbert J. Delatte, ${ }^{2}$ Member, ASCE
}

\begin{abstract}
The collapse of the L'Ambiance Plaza building, under construction in Bridgeport, Conn., in 1987, killed 28 construction workers. A number of concurrent investigations were undertaken to attempt to determine the cause. At least six separate theories were developed. However, a prompt legal settlement kept these investigations from being completed. This paper reviews the collapse and discusses the competing theories. The failure focused controversy on the safety of the lift-slab construction method. Because there is a need in civil engineering education for case studies to illustrate ethical and professional issues as well as technical principles, this paper also addresses these aspects. Ways for civil engineering educators to use this case study to address these issues also are discussed.
\end{abstract}

\section{INTRODUCTION}

The death of 28 workers in the construction collapse of the L'Ambiance Plaza building in Bridgeport, Conn., triggered a massive rescue effort and several investigations. Both the legal and engineering professions are interested in causes of failures. The legal profession seeks to assign responsibility, and the engineering profession seeks to learn from failures in order to eliminate poor designs and unsafe practices. Sometimes, as in the case of the investigation of the L'Ambiance Plaza collapse, the two objectives are in conflict.

For the engineer and engineering student, knowledge of engineering failures is just as important as knowledge of its successes. A success illustrates what engineering can make possible, whereas a failure demonstrates its limits. It takes numerous successful structures to ensure the quality of a design or a construction method. One failure, however, can discredit an entire design or building technique. Because of this, the information that each failure has to offer should be carefully studied and applied to all future designs. As a result similar failures, as well as their tragic consequences, can be avoided.

Because of their importance, failures should be incorporated into engineering education. Unfortunately, undergraduate engineering students receive little exposure to engineering failures in college. This approach to engineering education not only leaves students less prepared for what they will face after graduation, but it also fails to show the importance of continuing education (Delatte 1997). This may be one of the reasons that a 1983 survey of ASCE section and branch presidents found that engineering failures are all too common (Bosela 1993).

Because undergraduate engineering students already face an overcrowded curriculum, rather than requiring a new class covering failure case studies, these case studies can be incorporated into existing classes throughout a student's college career. Not only will this approach capture the students' interest by showing how their classes relate to engineering, but it also will inspire them to learn more about the history of the profession. In addition, it teaches them the importance of continued learning throughout one's professional career. Finally, failure case studies provide a perfect opportunity to discuss ethical concerns in real life situations as well as serve as a reminder of the repercussions of careless engineering (Delatte 1997). This is a topic that is often neglected in engineering education.

According to a 1987 survey conducted by the Committee of Education of the Committee on Forensic Engineering of ASCE, $63.2 \%$ of schools indicated that they would consider teaching a course on failure case studies if the appropriate materials were available. This clearly demonstrates the need for case study material and teaching aids to encourage the incorporation of failure case studies into the engineering curriculum (Rendon-Herrero 1993). The objectives of this paper are to

- Summarize what is known about the design, construction, and collapse of L'Ambiance Plaza

- Examine the causes of the failure as well as the legal ramifications

- Explore the technical, procedural, and ethical concerns present, focusing on how the failure could have been avoided and how to prevent similar failures in the future

This failure case study can be integrated into engineering classes to introduce new topics or as the topic of a short research paper.

\section{DESIGN AND CONSTRUCTION}

L'Ambiance Plaza was planned to be a 16-story building with 13 apartment levels topping three parking levels. It consisted of two offset rectangular towers, $19.2 \times 34.1 \mathrm{~m}(63 \times$ $112 \mathrm{ft}$ ) each, connected by an elevator (Fig. 1). Posttensioned concrete slabs 178-mm (7-in.) thick and steel columns comprised its structural frame (Cuoco et al. 1992). Posttensioning overcomes the tensile weakness of concrete slabs by placing high strength steel wires along their length or width before the concrete is poured. After the concrete hardens, hydraulic jacks pull and anchor the wires compressing the concrete (Levy and Salvadori 1992).

The lift-slab method of construction, patented by Youtz and Slick in 1948, was utilized in the construction of this building. Following this technique, the floors slabs for all 16 levels were constructed on the ground, one on top of the other, with bond breakers between them. Then packages of two or three slabs were lifted into temporary position by a hydraulic lifting apparatus and held in place by steel wedges. The lifting apparatus consisted of a hydraulic jack on top of each column, with a pair of lifting rods extending down to lifting collars cast in the slab.

Once the slabs were positioned correctly, they were permanently attached to the steel columns. Two shear walls in each tower were to provide the lateral resistance for the completed building on all but the top two floors. These two floors depended on the rigid joints between the steel columns and the concrete slabs for their stability. Because the shear wall 


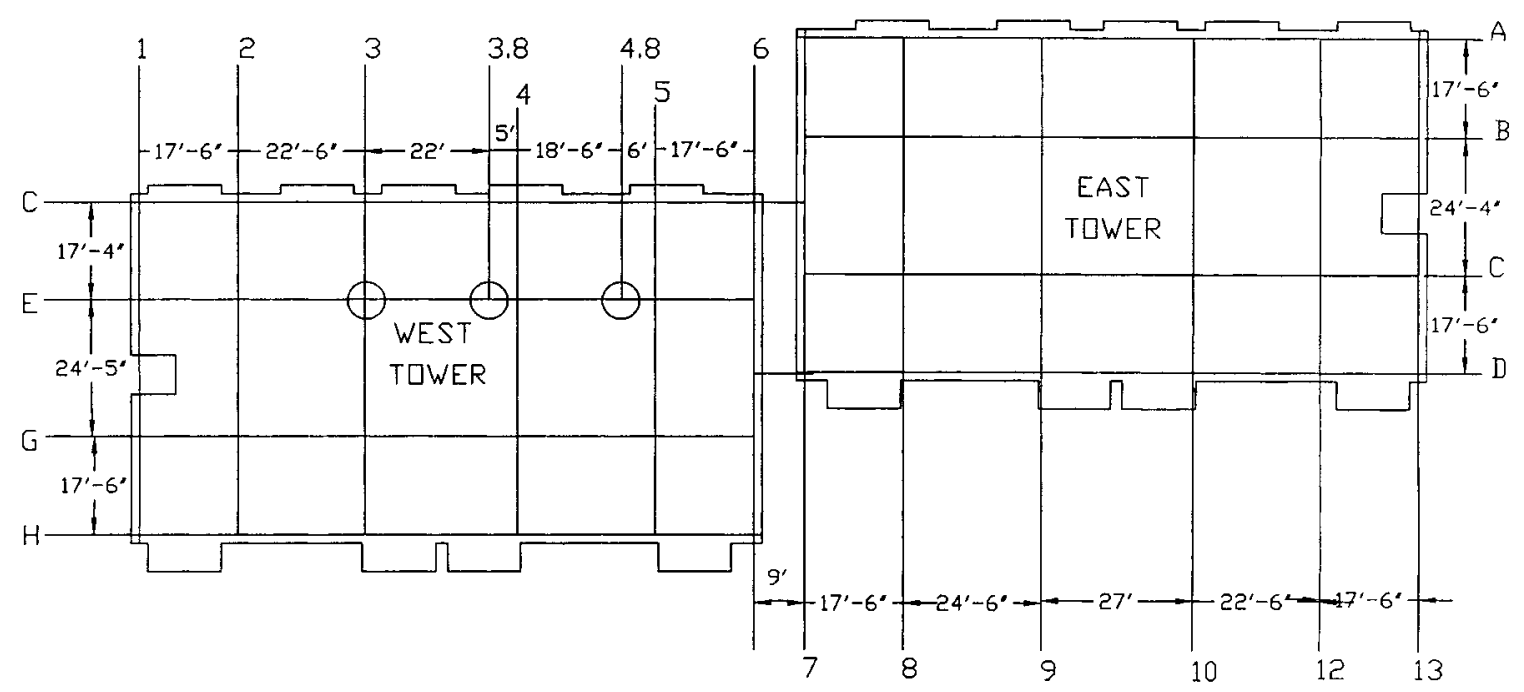

FIG. 1. Floor Plan of L'Ambiance Plaza

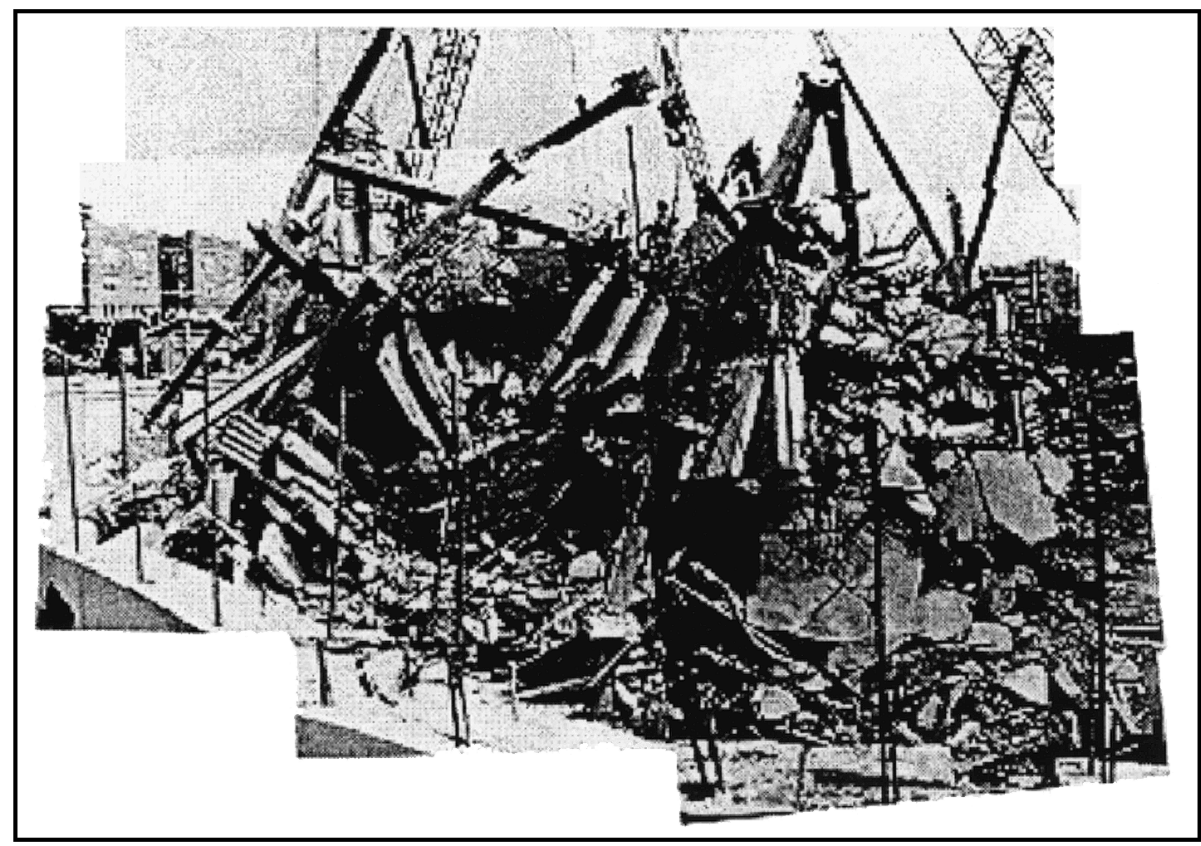

FIG. 2. Ruins of L'Ambiance Plaza (Image from Internet at 〈http://www.sgh.com/aplaza.htm〉)

played such an indispensable role in the lateral stability of the building, the structural drawings specified that during construction the shear walls should be within three floors of the lifted slabs (Heger 1991).

\section{COLLAPSE}

At the time of collapse, the building was a little more than halfway completed (Fig. 2). In the west tower, the 9th, 10th, and 11 th floor slab package was parked in Stage IV directly under the 12th floor and roof package (Fig. 3). The shear walls were about five levels below the lifted slabs (Cuoco et al. 1992).

The workmen were tack welding wedges under the 9th, 10 th, and 11th floor package to temporarily hold them into position when a loud metallic sound followed by rumbling was heard. Kenneth Shepard, an ironworker who was installing wedges at the time, looked up to see the slab over him "cracking like ice breaking." Suddenly, the slab fell onto the slab below it, which was unable to support this added weight and in turn fell. The entire structure collapsed, first the west tower and then the east tower, in $5 \mathrm{~s}$, only $2.5 \mathrm{~s}$ longer than it would

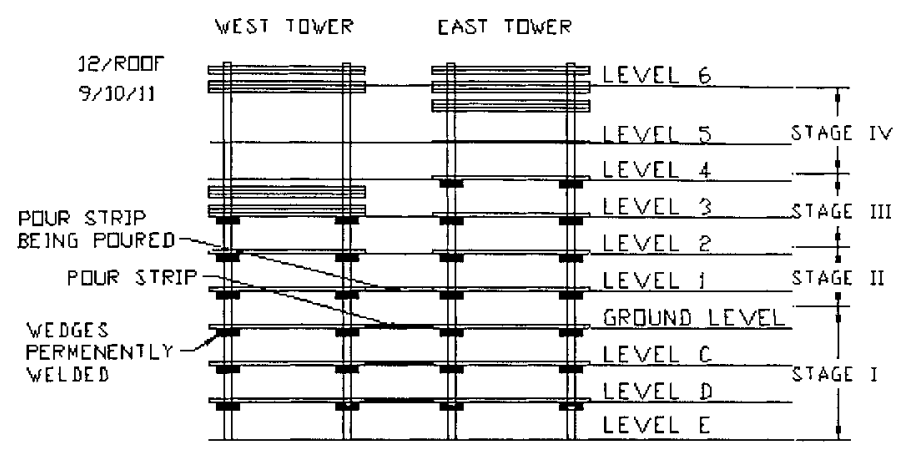

FIG. 3. Status of Construction at Time of Collapse [Based on Information from Cuoco (1992)]

have taken an object to free fall from that height. Ten days of frantic rescue operations revealed that 28 construction workers died in the collapse, making it the worst lift-slab construction accident. Kenneth Shepard was the only one on his crew to survive (Levy and Salvadori 1992). 


\section{CAUSES OF FAILURE}

An unusually prompt legal settlement prematurely ended all investigations of the collapse. Consequently, the exact cause of the collapse has never been established. The building had a number of deficiencies - any one of which could have triggered the collapse. The question, however, remains which one of these problems was in fact the triggering mechanism leading to the total collapse. There are six competing theories as to the trigger. Kaminetzky lists, but does not discuss, a seventh theory "failure resulting from lateral soil pressure acting on the foundation walls" (Kaminetzky 1991, p. 82).

- Theory 1: National Bureau of Standards (NBS), now the National Institute of Standards and Technology, Gaithersburg, Md. An overloaded steel angle welded to a shearhead arm channel deformed, causing the jack rod and lifting nut to slip out and the collapse to begin (Korman 1987).

- Theory 2: Thornton-Tomasetti Engineers-The instability of the wedges holding the 12th floor and roof package caused the collapse (Cuoco et al. 1992).

- Theory 3: Schupack Suarez Engineers, Inc. The improper design of the posttensioning tendons caused the collapse (Poston et al. 1991).

- Theory 4: Occupational Safety and Health Administration (OSHA), Washington, D.C.-Questionable weld details and substandard welds caused the collapse (McGuire 1992).

- Theory 5: Failure Analysis Associates, Inc. (FaAA)The sensitivity of L'Ambiance Plaza to lateral displacement caused its collapse through global instability (Moncarz et al. 1993).

- Theory 6: Oswald Rendon-Herrero-Rapid slump of a column footing precipitated the collapse (Rendon-Herrero 1994).

\section{Theory 1-Overloaded Steel Angle}

The NBS investigation concluded that the failure occurred at the building's most heavily loaded column, E4.8, or the adjacent column, E3.8, as a result of a lifting assembly failure (Fig. 4). The shearhead reinforces the concrete slab at each column, transfers vertical loads from the slabs to the columns, and provides a place of attachment for the lifting assembly. It consists of steel channels cast in the concrete slab, leaving a space for the lifting angle. The lifting angle has holes to pass the lifting rods through. These rods are raised by the hydraulic jacks on the columns above them (Levy and Salvadori 1992).

Shortly before the collapse, the workers lifted the 9th, 10th, and 11th floor package to its final position and began tack welding the steel wedges into place. They used a jack on top of the column, E4.8 or E3.8, to slightly adjust the position of the slab overloading the lifting angles. When the shearheads and lifting angles had lifted the package of three 3.13-MN (320-ton) slabs, they were dangerously close to their maximum capacity, so adding even the smallest of loads could strain them.

One of the reasons was that the lifting capacities of the two types of jacks used were too small for the 9.38-MN (960-ton) package being lifted. The regular jacks have a maximum load of $869 \mathrm{kN}$ (89 tons), and the superjacks have a maximum load of $1.47 \mathrm{MN}$ (150 tons). The NBS also tested the shearhead and lifting angle and found that they tended to twist as the loads approached $781 \mathrm{kN}$ (80 tons) because, although strong enough, they were not stiff enough. The excess force deformed the lifting angle, allowing the jack rod and lifting nut to slip out of the lifting angle and hit the column with $333 \mathrm{kN}(75,000$ lb) of force. This accounts for the loud noise that Kenneth

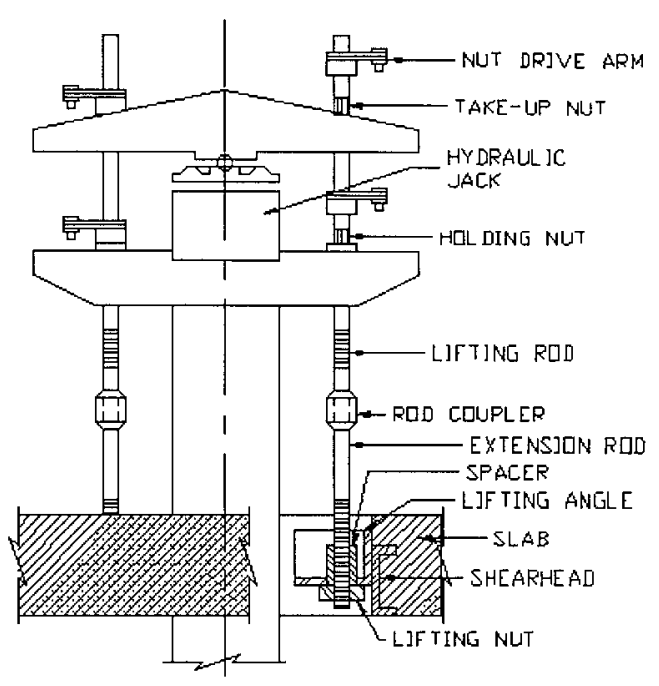

FIG. 4. Lifting Assembly

Shepard heard and the indentation found in that column. After this initial slip, the jack rods and lifting nuts in the entire E line progressively slipped, causing the ninth floor slab to collapse, which initiated the collapse of the entire building (Korman 1987). This theory was later abandoned by NBS in favor of Theory 4 (Culver and Marshall 1994).

\section{Theory 2-Unstable Wedges}

Thornton-Tomasetti Engineers concluded that the instability of the wedges at Column $3 \mathrm{E}$ caused the 12 th floor and roof package to fall, which initiated the collapse. They disagreed with the NBS investigation, finding that all the wedges supporting the 9 th, 10 th, and 11 th floor package were mounted prior to the collapse and that the column had no indentations on it. They, however, did find abnormal tack welds on the wedges that supported the 12th floor and roof package, a large deformation on the top edge of the west wedge of this set, and indentations on the underside of the Level 9 shearhead. The shallowness of the indentations indicated that, although both lifting nuts slipped out, they were not heavily loaded at the time.

Their investigation also found that the shearhead gaps on Columns $3 \mathrm{E}$ and $3.8 \mathrm{E}$ [16 $\mathrm{mm}$ (0.628 in.)] were much larger than the gaps on the rest of the building [5.92-8.31 mm $(0.233-0.327$ in. $)]$ and other buildings built with the lift-slab technique [6.35-9.53 $\mathrm{mm}(0.250-0.375 \mathrm{in})$.$] . In addition to$ these abnormally large gaps, the shearheads used on these two columns did not have cutouts in their lifting angles to restrict relative shifting and were installed eccentrically. Finally, until a wedge is completely welded into place, it depends on friction to hold it. Normally, this is sufficient. The large shearhead gaps on Columns $3 \mathrm{E}$ and $3.8 \mathrm{E}$ and the presence of hydraulic fuel on these wedges, however, would have demanded an extremely high friction coefficient to hold the wedges in place.

On the day of collapse, the lateral load from the hydraulic jack exerted on the heavily loaded wedges caused the west wedge to roll. Then the local adjustments to slab elevations caused the remaining wedge to roll out, which initiated the collapse of the 11th floor and roof package and the west tower (Fig. 5). Forces transmitted through the pour strips or the horizontal jack, or the impact of the debris from the west tower triggered the east tower's collapse (Cuoco et al. 1992).

\section{Theory 3-tmproper Design of Posttensioning Tendons}

Schupack Suarez Engineers, Inc. analyzed the structural behavior of a typical west tower floor slab, with respect to the 

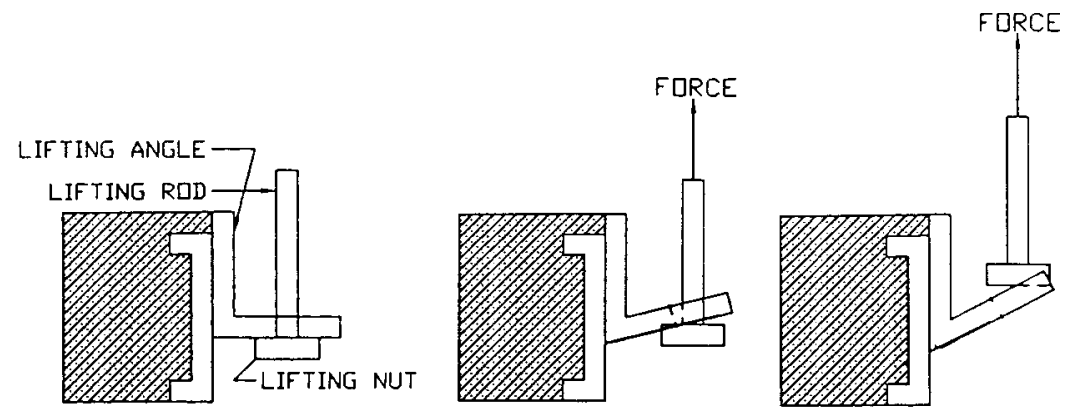

FIG. 5. Failure Sequence

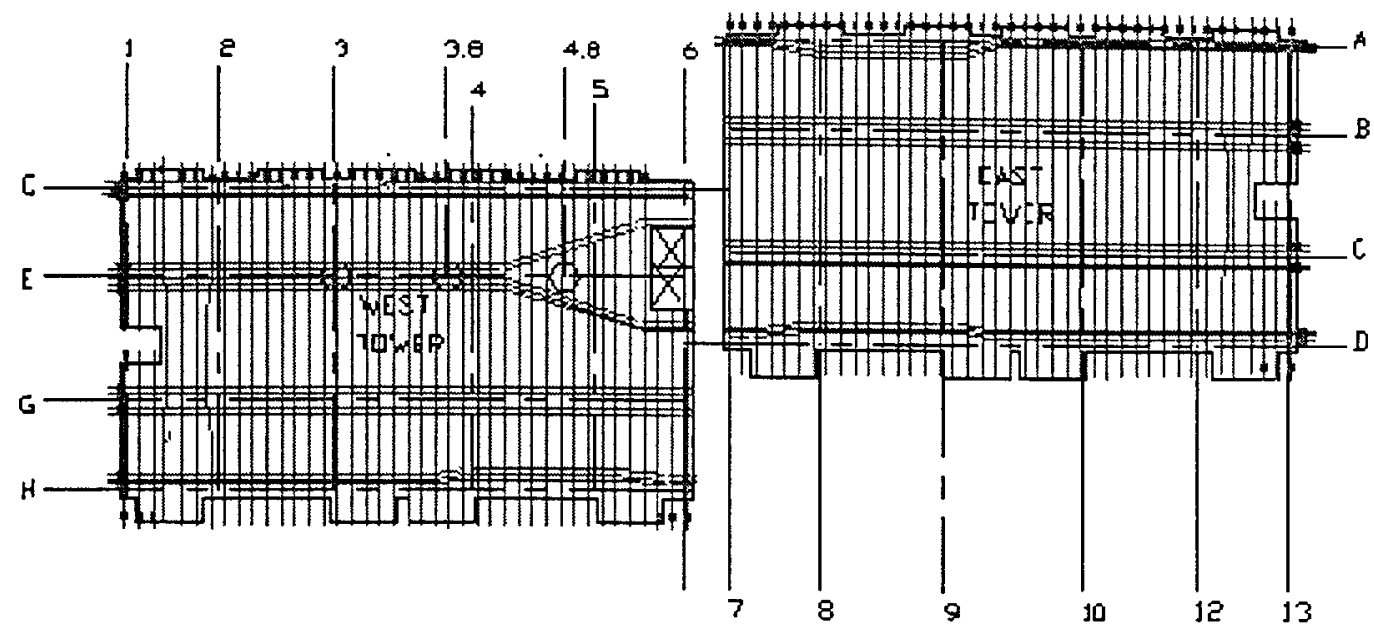

FIG. 6. General Layout of Posttensioning Tendons (Each Line Represents 1-5 Monostrand Tendons)

unusual layout of the posttensioning tendons (Fig. 6). The tendons in the east tower follow a typical two-way banded posttensioning tendon layout. In this layout the vertical tendons distribute the weight of the slab to the east-west column lines, which in turn distribute the weight to the columns. The west tower, however, deviates from this pattern. At Column $4.8 \mathrm{E}$ the tendons split in two, both diverging from the column line. In the west tower, the vertical tendons still distribute the slab's weight to the column line. In Line $\mathrm{E}$, however, there are no tendons to carry this weight. This setup violates the building code of the American Concrete Institute, Detroit. Kaminetzky pointed out that the code stipulates "a minimum of two tendons shall be provided in each direction through the critical shear section over columns" (Kaminetzky 1991, p. 84).

Furthermore, the design details of the posttensioned floor slabs do not show the location of the shear walls or the openings for the walls at Columns $11 \mathrm{~A}, 8 \mathrm{~A}$, and $2 \mathrm{H}$. The design did not take these openings into account. Detailed finite-element analysis showed that tensile stresses along Column Line E, east of Column 4.8E, exceeded the cracking strength of the concrete. Therefore once a crack began, it would immediately spread to Column 4.8E. In addition, under ideal lifting conditions, the analysis demonstrated that column $2 \mathrm{H}$ would have unsuitably high compressive and punching shear stresses (Poston et al. 1991).

\section{Theory 4-Poor Weld Details and Welds}

OSHA found that the header bar-to-channel welds on one side of the ninth-floor shearhead, at Column E3.8, had failed (Fig. 7). The use of one-sided square-groove welds for the header bar-to-channel connection was criticized because they were not prequalified joints, according to the American Welding Society. Because their penetration was not known, their strength could not be determined. OSHA hired Neal S. More-

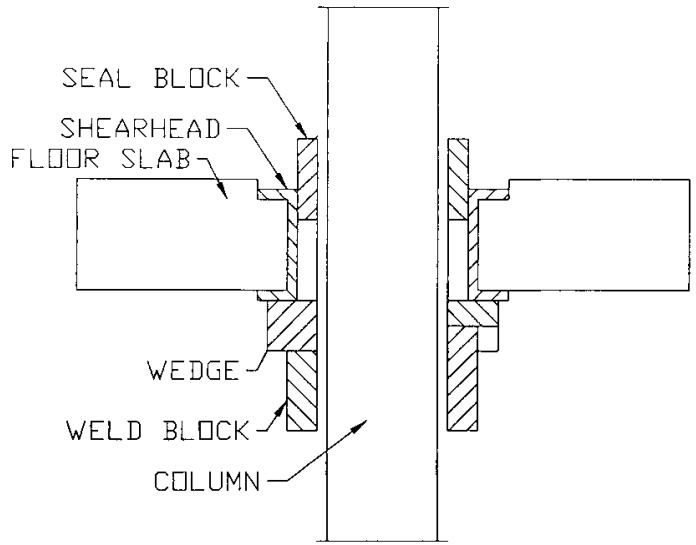

FIG. 7. Wedged Slab-to-Column Connection

ton and Associates to examine 30 welds around the shearheads at Column E3.8 at the 7th, 8th, and 10th floors. They found only 13 of the 30 welds acceptable; the other 17 were substandard. The questionable weld details and substandard welding, coupled with drawings that indicated that the welds would undoubtedly experience forces that they could not resist, all point to weld failure as the trigger of the collapse (McGuire 1992).

\section{Theory 5-Global Instability}

FaAA studied the tower's torsional stability and response to lateral loading to understand its collapse. When the concrete slabs are temporarily resting on the wedges, the connection is rotationally stiff but, as soon as the slab is lifted off one of the wedges into its final position, it can rotate freely from the column. Once the wedges are fully welded into their final po- 
sitions, the connection becomes rigid again. In the absence of lateral loading, the tower is completely stable.

Lateral loading and displacement, however, can cause the slab to lift off one of its wedges, causing the structure to become laterally flexible. FaAA used 3D computer modeling (ANSYS) and nonlinear stability modeling to study this phenomenon. Their investigation and analysis led them to the conclusion that the tower's sensitivity to lateral displacement caused its collapse. Although FaAA analysts acknowledge that another mechanism could have triggered the lateral displacement, they believe that lateral jacking provided sufficient displacement to initiate the collapse (Moncarz et al. 1993).

\section{Theory 6-Foundation Failure}

In a discussion to Cuoco et al.'s 1992 paper, Rendon-Herrero suggested that "a closer look warrants reconsideration of the role played by the foundation in the collapse" (RendonHerrero 1994). He noted the the NBS report found disintegrated rock and bedrock and fill materials of varying quality. The report also questioned whether testing of in-place density had been performed and the rationale for the assumption of the allowable bearing pressure. He concluded that "the writer feels that descriptions like 'mica,' 'micaceous schist,' 'highly fractured,' 'cracks,' 'disintegrated rock,' 'fill,' 'compaction with backhoe,' 'highly weathered,' 'thinly laminated,' and 'very steep dip (nearly vertical)' are red flags that indicate the need for caution and special attention in the design of a foundation. Punching or local shear is likely when subgrade conditions include loose granular soils (i.e., inadequate compaction); micaceous soils; micaceous schists; and highly fractured, steeply dipping bedrock" (Rendon-Herrero 1994).

\section{LEGAL REPERCUSSIONS}

All of these theories are plausible, but what triggered the collapse? That may never be known. A two-judge panel mediated a universal settlement between 100 parties, which closed the L'Ambiance Plaza case. Twenty or more separate parties were found guilty of "widespread negligence, carelessness, sloppy practices, and complacency." They all contributed, in varying amounts, to the $\$ 41,000,000$ settlement fund. Those injured and the families of those killed in the collapse received $\$ 30,000,000$. Another $\$ 7,600,000$ was set aside to pay for all of the claims and counterclaims between the designers and contractors of L'Ambiance Plaza.

Although this settlement kept hundreds of cases out of court and provided rapid closure to a colossal collapse, it also ended all investigations prematurely, leaving the cause of the collapse undetermined (Korman 1988). Fortunately, many of the investigators subsequently published their findings (Feld and Carper 1997).

\section{TECHNICAL ASPECTS}

Although buildings constructed by the lift-slab method are stable once they are completed, if great care is not taken during construction, they can be dangerous. Feld and Carper (1997) reviewed a number of previous lift-slab construction failures and near failures. The following measures can be taken to ensure lateral stability and safety during construction:

- During all stages of construction, temporary lateral bracing should be provided, unless the lateral stability of the structure is provided through another mechanism.

- Concrete punching shear and connection redundancies should be provided in the structure (Kaminetzky 1991).

- Sway bracing (cables that keep the stack of floors from shifting sideways) should be used. This was required, but not used in L'Ambiance Plaza (Levy and Salvadori 1992).
Due to the terms of the settlement, many of the technical lessons that could have been learned from this incident were lost.

\section{PROFESSIONAL AND PROCEDURAL ASPECTS}

The L'Ambiance Plaza collapse highlighted several procedural deficiencies. Responsibility for design was fragmented among so many subcontractors that several design deficiencies went undetected. If the engineer of record had taken responsibility for the overall design of the building or a second engineer had reviewed the design plans, these defects probably would have been detected (Heger 1991). Also, standardized step-by-step procedures for lift-slab construction should be established to ensure the safety of the construction workers. A licensed professional engineer should be present during construction to ensure that these guidelines are followed (Kaminetzky 1991).

\section{ETHICAL ASPECTS}

Although the L'Ambiance Plaza building was designed to be safe once it was completed, during construction it did not have an adequate level of stability. This is all too common in the construction industry today (Heger 1991). Canon 1 of the ASCE Code of Ethics states, "Engineers shall hold paramount the safety, health and welfare of the public and shall strive to comply with the principles of sustainable development in the performance of their professional duties" (ASCE 1998). This includes the safety of construction workers. Building regulations do not sufficiently consider structural safety during construction and should be changed to require a high standard of safety during construction as well as after a building's completion. In the absence of such regulations, however, an ethical engineer must always consider the safety of workers (Heger 1991).

\section{EDUCATIONAL ASPECTS}

Failure plays an important role in engineering practice. Through failure analysis, engineers can learn to avoid similar technical errors, which allows them to build stronger, safer structures. Because failure analysis plays such an integral role in a good engineer's professional career, it only makes sense that, in college, engineering students should be taught how to analyze engineering failures as well as their importance to any engineer's professional life. In light of an already overcrowded undergraduate engineering curriculum, integrating failure case studies into already existing engineering classes is the most logical solution.

This approach gives students a better idea of the obstacles that will face them after graduation, in addition to demonstrating how the theoretical ideas taught in their classes are actually applied by engineers. The only real obstacle that lies in the way of increased failure awareness at an undergraduate level is the absence of adequate resources, such as well-developed failure case studies and appropriate illustrations. This paper provides professors and students with a failure case study that can be integrated into undergraduate classes.

How can educators use these case studies? In structural analysis courses, they can be used to address technical topics such as safety during construction, load paths, and integrity of connections. Students may be assigned to research the literature in greater depth and support or criticize the available theories. For engineering students, the legal ramifications of the case may be of even greater interest. Two additional important points that may be made are the importance of fixing overall responsibility on a project before difficulties are encountered and the need to read the literature of the profession to keep up with technical and procedural advances. The ambiguity of 
the outcome of this case can be used to advantage when teaching students in upper division courses, by emphasizing how much they still have to learn about the technical challenges of the profession.

\section{CONCLUSIONS}

The L'Ambiance Plaza collapse killed 28 workers and had serious ramifications for all involved with the project as well as for the civil engineering profession as a whole. All of the theories discussed above are plausible, but it seems unlikely that the triggering mechanism of the collapse can ever be determined. There remain, nevertheless, valuable technical, professional, procedural, and ethical lessons from this case for engineering students and practitioners.

\section{ACKNOWLEDGMENTS}

This research was supported by the National Science Foundation, Washington, D.C., as part of the University of Alabama at Birmingham's Research Experiences for Undergraduates Site in Structural Engineering under grant EEC-9820484. The second writer would like to thank Oswald Rendon-Herrero for bringing Theory 6 to his attention. In addition, the paper reviewers made many excellent comments that were incorporated into the final manuscript.

\section{APPENDIX. REFERENCES}

ASCE. (1998). ASCE Code of Ethics, Reston, Va.

Bosela, P. A. (1993). "Failure of engineered facilities: Academia responds to the challenge." J. Perf. Constr. Fac., ASCE, 7(2), 140-144.

Culver, C. G., and Marshall, R. D. (1994). "Discussion of 'Investigation of L'Ambiance Plaza building collapse,' by Daniel A. Cuoco, David B. Peraza, and Thomas Z. Scarangello." J. Perf. Constr. Fac., ASCE, 8(2), $160-161$.

Cuoco, D. A., Peraza, D. B., and Scarangello, T. Z. (1992). "Investigation of L'Ambiance Plaza building collapse.” J. Perf. Constr. Fac., ASCE, 6(4), 211-231.

Delatte, N. J., Jr. (1997). “Integrating failure case studies and engineering ethics in fundamental engineering mechanics courses." J. Profl. Issues in Engrg. Educ. and Pract., ASCE, 123(3), 111-116.

Feld, J., and Carper, K. (1997). Construction failure, 2nd Ed., Wiley, New York.

Heger, F. J. (1991). "Public-safety issues in collapse of L'Ambiance Plaza." J. Perf. Constr. Fac., ASCE, 5(2), 91-112.

Kaminetzky, D. (1991). Design and construction failures: Lessons from forensic investigations, McGraw-Hill, New York.

Korman, R. (1987). "Flawed connection detail triggered fatal L'Ambiance Plaza collapse." ENR, October 29.

Korman, R. (1988). "Mediated settlement seeks to close the book on L'Ambiance Plaza." ENR, November 24.

Levy, M., and Salvadori, M. (1992). Why buildings fall down: How structures fail, W. W. Norton, New York.

McGuire, W. (1992). "Comments on L'Ambiance Plaza lifting collar/ shearheads." J. Perf. Constr. Fac., ASCE, 6(2), 78-85.

Moncarz, P. D., Hooley, R., Osteraas, J. D., and Lahnert, B. J. (1993). "Analysis of stability of L'Ambiance Plaza lift-slab towers." J. Perf. Constr. Fac., ASCE, 6(4), 232-245.

Poston, R. W., Feldmann, G. C., and Suarez, M. G. (1991). "Evaluation of L'Ambiance Plaza post-tensioned floor slabs." J. Perf. Constr. Fac., ASCE, 5(2), 75-91.

Rendon-Herrero, O. (1993). "Too many failures: What can education do?" J. Perf. Constr. Fac., ASCE, 7(2), 133-139.

Rendon-Herrero, O. (1994). "Discussion of 'Investigation of L'Ambiance Plaza building collapse,' by Daniel A. Cuoco, David B. Peraza, and Thomas Z. Scarangello." J. Perf. Constr. Fac., ASCE, 8(2), 162-164. 